\title{
The Effect of Fiscal Policy on Economic Development in Jordan
}

\author{
Ali Sulieman Al-Shatti ${ }^{1}$ \\ ${ }^{1}$ Dept. of Banking and Financial Sciences, Philadelphia University, Jordan \\ Correspondence: Ali Sulieman Al-Shatti, Dept. of Banking and Financial Sciences, Philadelphia University, \\ Jordan. E-mail: Alialshati2008@gmail.com
}

Received: October 1, 2014

Accepted: October 21, 2014

Online Published: November 25, 2014

doi:10.5539/ibr.v7n12p67

URL: http://dx.doi.org/10.5539/ibr.v7n12p67

\begin{abstract}
This research aims to examine the effect of the fiscal policy on economic development in Jordan during the time period (1989-2013), a mathematical model has been designed to measure this effect on economic development in Jordan. The researcher found that there is a statistically positive significant effect of the current expenses and annual tax revenues on economic development in Jordan, and at the same time there is a statistically negative significant effect of the capital expenditures on economic development in Jordan. The empirical results show that the elements of fiscal policy considered in this study are important variables in explaining economic development in Jordan, and the joint effect of the fiscal policy elements (annual tax revenues, current expenditures and capital expenditures) on economic development is statistically significant. In sum, current expenditures In contrast to taxes, give more per capita income returns. The fiscal adjustments based on capital expenditures reductions accompanied by efficiency in tax revenues collection have been considered as one of the successful forms of policy for increasing per capita income and promoting economic development simultaneously.
\end{abstract}

Keywords: economic development, fiscal policy, tax revenues, public expenditures

\section{Introduction}

Governments apply various financial and economic policies, in order to help their people through the efficient and optimum utilization of available resources, with the aim of producing goods and services that enable them as much as possible to satisfy the needs of their people. Whether governments have a direct or indirect production role, it is their responsibility to provide the conditions and to overcome the obstacles which hinder the production processes and the efficient utilizing of the available resources, in order to achieve greater prosperity for its people, which represents the ultimate goal of the various policies of the government.

One of these policies is fiscal policy which performs a significant function in affecting the direction of Jordan economy. The term fiscal policy refers to two major governmental economic activities taxation and spending. Where almost every act of government taxation and spending has a redistributive effect on it. So, politics usually plays an important role in shaping the nature of fiscal policy (Andolfatto).

True economic growth and development occur when various projects are financed and carried out using borrowed funds. This stems from the belief that the private sector cannot grow the economy by itself. Instead, some government input and influence are needed. Borrowing funds for this economic growth is one way in which the government brings about development. This economic model developed by John Maynard Keynes has been adopted in various forms since the World War II era.

Thus, the study tries to answer the following main question (Does the application of the fiscal policy assists the Jordanian government in achieving the desired economic development for the Jordanian people during the study period (1989-2013), and then answering the following sub-questions:

1). Do the annual tax revenues collected from the tax-payers; assist the government in achieving the economic development in Jordan?

2). Do the current public expenditures spent on a various activities and areas; assist the government in achieving the economic development in Jordan?

3). Do the capital public expenditures spent on a various activities and areas; assist the government in achieving the economic development in Jordan? 
Based on the study questions, the study seeks to achieve the following objectives:

1). Examine the effect of the annual tax revenues in achieving the economic development.

2). Examine the effect of the current public expenditures in achieving the economic development.

3). Examine the effect of the capital public expenditures in achieving the economic development.

The objective of this paper is to examine the effect of fiscal policy on economic development in Jordan throughout the study period 1989-2013, the researcher choose one single country with an attempt to make a more in-depth investigation and analysis, in that it investigates the partial and joint effects of fiscal policy on economic development in Jordan using certain disaggregated elements of fiscal policy.

The study is organized as follows: Section two presents an extensive review of literature on the effect of fiscal policy on economic development. Section three spells out the methodological approaches used in this study. While Section four focuses on the analysis of the research hypotheses, and to show the contribution of the study results in the provision of a new addition to previous studies. Finally, section five suggests the significance of these findings for decision makers in Jordan, and the recommendations reached by the researcher.

\section{Literature Review}

This section discusses some empirical and theoretical researches and publications on the effect of fiscal policy on economic development, and introduces an overview of Jordanian economy, and lastly presents the study hypothesis.

\subsection{Theoretical Literature}

There is a widespread controversy among policymakers about the effect of fiscal policy on achieving economic development.

The fiscal policies may exert important macroeconomic effects, especially short term, the use of different instruments leading to differenced results (Skinner, 1992). Thus, a change in the budgetary expenses determine a raise of the public economic sector, while a decrease of the tax rate will make the permanent available income raise, leading to the increase of the consumption expenses, implicitly, to the development of the private economic sector. The choice between the two instruments will be made according to the social benefits expected to be obtained from a larger consumption of more products and services that are oriented to the public area (Bebeşelea, Mitran and Neguriță).

The direct and indirect effects of fiscal policy on aggregate spending in the community were clearly established and as a result the budgetary policy of the government as a weapon of economic control and development came into prominence. The fiscal policy can affect the rate of economic development in a variety of ways such as by increasing the rate of saving and investment, affecting the allocation of resources, controlling inflation, promoting economic stability (Chand).

Wagner's law states that "as per capital income of an economy grows, there will be increase in the number of urban centers with the associated social vices such as crime which requires the intervention of the government to maintain law and order and these interventions by the government have lots of implications, leading to the increase in public expenditure in the economy` (Likita, 1999, pp. 45-46).

Wagner in his model identified that there is a positive relationship between the per capital income of the people in a state with public expenditures such that the income elasticity of public expenditures is always more than one. However, other researchers have discovered that the relationship is not always certain because there are periods when government expenditure in relations to the national income will decline when the elasticity of income to government expenditure is less than one (Inelastic) (Wagner \& Warren, 1977).

Peacock and Wiseman (1979) argue that temporary increases in government expenditures due to "crises" can lead to permanent increases in government revenues often called the "displacement effect" (Henrekson,1990).

Rostow and Musgrave in their model executed a research on growth of government spending and inferred that, there are three steps in the development process could be distinguished: at the early stages of economic development, the rate of growth of public expenditure will be very high because government provides the basic infrastructural facilities (social overheads) and most of these projects are capital intensive, therefore, the spending of the government will increase steadily. The investment in education, health, roads, electricity, and water supply are necessities that can launch the economy from the traditional stage to the take off stage of economic development making government to spend an increasing amount with time in order to develop an egalitarian society (Ogba \& Likita, 1999). They also suggested that the growth of public expenditure might be 
related to the pattern of economic growth and development in societies (Gow \& Mallick, 2005).

\subsection{Empirical Review}

A number of researches have examined the effect of fiscal policy on the economic development in developed and developing countries like Jordan. The results varied from one research to another as follows.

Dye and Merriman (1999) in their research entitled "The Effects of Tax Increment Financing on Economic Development", they found a proof that cities which select Tax increment financing develop less than those that do not.

KAKAR, (2002) in his paper entitled "impact of Fiscal Variables on Economic Development of Pakistan". Found that fiscal policy is very important for sustainable economic Development in Pakistan and fiscal policy measures are more suitable for long-run phenomena.

M'Amanja and Morrissey (2005) in their paper entitled "Fiscal Policy and Economic Growth in Kenya", found that unproductive expenditure and non-distortionary tax revenue to be neutral to growth as predicted by economic theory, and productive expenditure has strong adverse effect on growth whilst there was no evidence of distortionary effects on growth of distortionary taxes.

Bandyopadhyay and Esteban (2007) in their study "Redistributive Taxation and Public Expenditures" They show that there is a unique income tax schedule that is universally acceptable. The progressivity of the income tax is shown to depend on the composition of the public expenditure and on the substitutability between the goods and services supplied by the government and the consumption goods privately obtained through the market.

Wolff and Zacharias (2007) found that the overall income inequality declined significantly in line with net government expenditures. And the expenditures offer greater inequality-reduction results more than taxes.

Olabisi (2009) in his study entitled "Tax incentive as a catalyst for economic development in Nigeria", aims to assess the relationship that exists between tax incentive and economic development in Nigeria. It was found that tax incentive would enhance economic growth and development in Nigeria, if such incentives are well focused and extended to all deserving companies in the country.

Kitao (2010) found that fiscal policy, tax-reduction and discount transfer enhance the well-being of individuals and the discount policy achieve advantages for low-income individuals.

Al-Zeaud, et al (2011) examined the dynamic impact of fiscal policy on the economic position of Jordan within 1992-2009, he found that there is a positive impact of changes in exports and public expenditures on real (GDP) in the medium and long period, and changes in public expenditures and export lead to inflationary pressures in the short and long period.

Muinelo and Sagalés (2011) found that an increase in public investment reduces inequality without harming output while larger current expenditures and direct taxes diminish economic growth and reduce inequality.

Peñalosa and Turnovsky (2011) found that changes in tax policies reduce the labor supply and output, and they also distribute the after-tax income more equally.

AL- khasawneh and Abu Aleqa (2012) found that the growth rate in real gross domestic product (GDP) is based on previous growth rates in real GDP, government spending, government revenues and the terms of trade.

Udu (2012) concluded that there is a significant causal relationship between (GDP) and the research variables, and between exports and (GDP) and hence fiscal policies.

Claus et al. (2012) concluded that public spending is more effective than tax systems in the process of redistributing income.

Ibi and Opue (2012) investigated the effect of fiscal policy measures on economic development in Nigeria. They found that fiscal policy measures have not been effective in the development of the Nigerian economy when compared to monetary policy measures.

Kamaldeen et al. (2013) in their study entitled "Corruption and economic development: Evidence from Nigeria", found that there is a negative impact of corruption on economic growth and development.

Abu Shihab (2014) found that there is a causal relationship going from the economic growth to budget deficit, and not vice versa. Based on the outcome of causality tests, the changes in the economic growth help explain the changes that occur in the budget deficit.

This study improves on some of the existing studies, in that it investigates the partial and joint effects of fiscal policy on economic development in Jordan using certain disaggregated elements of fiscal policy. It also 
contributes to the existing literature on the long run effect of fiscal policy on economic development in Jordan.

\subsection{Jordan's Economy}

Jordan's economy is among the smallest in the Middle East, with insufficient supplies of water, oil, and other natural resources underlying the government's heavy reliance on foreign assistance. Other economic challenges for the government include chronic high rates of poverty, unemployment, inflation, and a large budget deficit. Since assuming the throne in 1999, King ABDALLAH has implemented significant economic reforms, such as opening the trade regime, privatizing state-owned companies, and eliminating some fuel subsidies, which in the last decade spurred economic growth by attracting foreign investment and creating some jobs. The global economic slowdown and regional turmoil, however, have depressed Jordan's GDP growth, impacting export-oriented sectors, construction, and tourism. In 2011 and 2012, the government approved two economic relief packages and a budgetary supplement, meant to improve the living conditions for the middle and poor classes. Jordan's finances have also been strained by a series of natural gas pipeline attacks in Egypt, causing Jordan to substitute more expensive diesel imports, primarily from Saudi Arabia, to generate electricity. Jordan is currently exploring nuclear power generation in addition to the exploitation of abundant oil shale reserves and renewable technologies to forestall energy shortfalls. In 2012, to correct budgetary and balance of payments imbalances, Jordan entered into a $\$ 2.1$ billion, multiple years International Monetary Fund Stand-By Arrangement. Jordan's financial sector has been relatively isolated from the international financial crisis because of its limited exposure to overseas capital markets. In 2013, Jordan depended heavily on foreign assistance to finance the budget deficit, as the influx of about 600,000 Syrian refugees put additional pressure on expenditures (Index mundi, Jordan Economy Profile 2014).

\subsection{Research Hypotheses}

The research hypotheses can be formulated as follows:

The fiscal policy hasn't an effect in achieving the economic development in Jordan.

From the above hypotheses, the sub- hypothesis can be formulated as follows:

1). The annual tax revenues haven't an effect in achieving the economic development in Jordan.

2). The current public expenditures haven't an effect in achieving the economic development in Jordan.

3). The capital public expenditures haven't an effect in achieving the economic development in Jordan.

\section{The Methodology and Model}

\subsection{Data}

This research tries to inspect the effect of fiscal policy on economic development in Jordan throughout the period (1989-2013) by utilizing the data of the annual reports of the Jordanian ministry of finance, General budget department, Department of Statistics.

Model Specification

The following model represents the study model which formulated as follows:

$$
Y=B 0+B 1 X 1+B 2 X 2+B 3 X 3
$$

Where: Y: represents the economic development measured by per capita income.

$\mathrm{X} 1$ : The annual tax revenues.

$\mathrm{X} 2$ : The current public expenditures.

X3: The capital public expenditures.

B1, B2 and B3: represents the coefficients values of the three independent variables, respectively.

B0: represents the value of the vertical section.

\subsection{Research Variables Definition}

The independent variables: Represent the fiscal policy tools.

Fiscal policy is the means by which a government adjusts its spending levels and tax rates to monitor and influence a nation's economy (Investopedia).

The main fiscal policy tools are the government expenditures (capital and current expenditures), as well as annual tax revenues, and these variables were chosen to represent the basic tools of fiscal policy in Jordan, as follows: 
1). The annual tax revenues.

2). The annual current public expenditures.

3). The annual capital public expenditures.

The dependent variable: Represent the economic development measured by the per capita income of the Jordanian people.

There are other measures of economic development in any country, including a measure of GDP which is a measure of the increase in real national income over a given period of time (economic growth), but this measure (GDP) tells nothing about the distribution of a societies' income, as expressed in the economic development.

Some economists believe that economic growth is meaningless as it does not improve the standard of living of the common masses. According to this view economic development should be defined as a process by which the real per capita income increases over a long period of time. Harvey Leibenstein, Rostow, Baran, Buchanan and many others favor the use of the per capita income as an index of economic development. The UNO experts in their report on 'Measures of Economic Development of Underdeveloped Countries' have also accepted this measurement of economic development. (Preserve articles). "If an increase in per capita income is taken as the measure of economic development, we would be in the awkward position of having to say that a country had not developed if its real national income had risen but population had also risen at the same rate" (Somashekar).

Table 1. Variables definition \& measurement units

\begin{tabular}{clc}
\hline Variables symbols & Variables explanations & Measurement unit \\
\hline PCI & Real Per Capita Income & Ln PCI \\
TXR & Real Annual Tax Revenues & Ln TXR \\
CPE & Real Current Public Expenditures & Ln CPE \\
KPE & Real Capital Public Expenditures & Ln KPE \\
\hline
\end{tabular}

\subsection{Data Analysis}

This research applies the descriptive and econometrics analysis approach in determining the effect of fiscal policy on economic development in Jordan during the time period (1989-2013), and so that we use the multiple regression method, which is being estimated by the least squares method (OLS), through applying the statistical program (E-Views) on the time series data related to components of fiscal policy and per capita income during the study period, from the annual accounts issued by the General Budget Department, and the Department of Statistics, and the relevant previous studies conducted on Jordan and other countries around the world. Where, the research tries to determine the partial and joint effect of fiscal policy on economic development in Jordan.

\subsection{Statistical Analysis and Interpretation}

\subsubsection{Unit Root Test Results}

Stationary of the expletory variables and dependent variable for the research model, (Ln PCI) was tested by using Augmented Dickey Fuller (ADF) test. Table 2 views the results which indicate the rejection of the unit root null hypothesis of the stationary of the Ln of (TXR, CPE, KPE) and Ln PCI at the first difference.

Table 2. The results of unit root tests

\begin{tabular}{cccc}
\hline Variables & ADF Statistics & P- Value & Order of Integration \\
\hline Ln PCI & -3.970118 & 0.0004 & I (1) \\
Ln TXR & -3.455777 & 0.0192 & I (1) \\
Ln CPE & -5.073408 & 0.0005 & I (1) \\
Ln KPE & -6.820221 & 0.0000 & I (1) \\
\hline
\end{tabular}

Source: Author computation from computer output. 


\subsubsection{Testing for the Suitability of the Model}

To examine the suitability of the multiple regression models for analysis, by using the distribution (F-Fisher) test, one of the following hypotheses will be rejected;

Ho: the model is not appropriate; if the independent variables don't affect the dependent variable.

H1: the model is appropriate; if the independent variables do affect the dependent variable.

The decision rule will be:

Accept H0 If (Sig. F) $>5 \%$.

Accept H1 If (Sig. F) $<5 \%$.

From the analysis output, the value of (Sig. F) equals to (0.0000) which is less than $5 \%$. This means the model used is appropriate, that there is a statistically significant effect of fiscal policy on economic development in Jordan.

And we note that the total change in the dependent variable demonstrated by the independent variables ( Rsquared ) equals to (0.832373) which is statistically significant at the level of less than $(0.05)$ where (Sig. $\mathrm{R}=$ 0.000 ), and the value of the determination coefficient (adjusted R- squared ) equals to (0.808426).

\subsubsection{The Correlation Analysis Test}

To examine the correlation between the dependent variable and the independent variables, we accept one of the following hypotheses:

$\mathrm{H} 0$ : There is no correlation between fiscal policy and economic development.

H1: There is a correlation between fiscal policy and economic development.

The decision rule as follow

Accept $\mathrm{H} 0$ if (Sig. R) $>5 \%$.

Accept $\mathrm{H} 1$ if (Sig. R) $<5 \%$

The analysis outputs show that the significant of the correlation value equals to (Sig. $R=0.000$ ), that there is a statistically significant correlation between fiscal policy and economic development.

\subsubsection{The Research Hypotheses Test}

The following model used to investigate the effect of the independent variables on economic development, as follows:

$$
Y=a \pm \beta 1(X 1) \pm \beta 2(X 2) \pm \beta 3(X 3)
$$

To examine the total variation in the dependent variable explained by the independent variables, we accept one of the following hypotheses:

Ho: There is no statistically significant effect of fiscal policy on economic development.

H1: There is a statistically significant effect of fiscal policy on economic development.

Table 3. Coefficients of the independent variables

\begin{tabular}{ccc}
\hline Variables & Coefficients & Sig. t \\
\hline X1 & 0.006750 & 0.011 \\
X2 & 0.911097 & 0.000 \\
X3 & -0.413467 & 0.000 \\
Constant & 2.778795 & 0.013 \\
\hline
\end{tabular}

Source: Author computation from computer output.

Based on the coefficients values in the table above, the regression equation will be written as follows:

$$
Y=2.778795+0.006750(X 1)+0.911097(X 2)-0.413467(X 3)
$$




\section{Findings}

The research aims at examining the effect of fiscal policy on economic development in Jordan during the time period (1989-2013), in that it investigates the joint and partial effects of fiscal policy elements on economic development in Jordan using certain disaggregated elements of fiscal policy (current and capital expenditures, tax revenues).

The empirical results show that there is a statistically positive significant effect of the annual tax revenues and of the current expenditures on economic development in Jordan.

This is in agreement with Olabisi (2009) who found in that his study tax incentive would enhance economic growth and development in Nigeria, if such incentives are well focused and extended to all deserving companies in the country, and with Ocran (2009) who found that tax receipts have a positive effect on economic growth and development in South Africa.

But this is contrary to what Muinelo-Gallo and Roca-Sagalés (2011) found in their study that larger current expenditures and direct taxes diminish economic growth and reduce inequality.

There is also a statistically negative significant effect of the capital expenditures on economic development in Jordan. This is in agreement with M'Amanja and Morrissey (2005) in that productive expenditure has strong adverse effect on growth while there was no evidence of distortionary effects on growth of distortionary taxes. And this is contrary to what Todaro concluded that the economic development requires an increase in government expenditures with an increase in economic activities.

The joint effect of the fiscal policy tools (annual tax revenues, current expenditures and capital expenditures) on economic development is statistically significant as indicated by the computed F-Statistic and its probability. Therefore, the study submits that there is an effect of fiscal policy on economic development, and that the tax revenues and the current expenditure exert a positive significant effect, but the capital expenditures show a negative effect on economic development.

This is contrary with the results of Ibi and Opue (2012) in their study entitled "Fiscal Policy and Economic Development in Nigeria (1960-2011)", where the collective results of the study reveal that fiscal policy measures have not been effective in the development of the Nigerian economy when compared to monetary policy measures.

The analysis results also show that the explanatory variables applied in the model illustrate about $81 \%$ of divergences in the explained variable. This implies that within the context of the model, fiscal policy explained about $(81 \%)$ of variability in economic development during the study period. This high explanatory power shows that the model is a good fit, and that these components of fiscal policy are important determinants of economic development in Jordan.

\section{Summary and Conclusions}

The study further concludes that the elements of fiscal policy considered in this study are important variables in explaining economic development in Jordan. Based on findings from the empirical analysis, the study offers the following recommendations, through which they can work to improve financial decisions making and to have an effective role in achieving economic development, and support growth, as follows:

Tax incentives would enhance economic growth and development in Jordan, if such incentives are well focused and extended to all deserving taxpayers in the country. Suggestions should be made as to variables moderating the tax incentive and economic development. Even though tax structure tend to be cumulative system, government spending is still a more effective instrument for redistributing income. Current expenditures appear to increase per capita income and capital expenditures appear to increase income inequality.

Capital and current expenditures should be directed mainly to serve the economic development of the country by concentrating on productive economic activities that promote economic development, even managed to improve the efficiency of utilization of existing productive capacity. This will stimulate activities in the economic sectors and, perhaps, reverse the negative effect of capital expenditures on economic development.

Since the analysis showed that current expenditure has more positive effect on economic development than the capital expenditures, they require more favorable attention in the allocation of public expenditures.

In sum, current expenditures in contrast to taxes, give more per capita income returns. The fiscal adjustments based on capital expenditures cuts accompanied by efficiency in tax revenues collection have been considered as one of the successful forms of policy for increasing per capita income and promoting economic development simultaneously. 
There is a need to conduct research and other studies to investigate in depth the effect of fiscal policy on economic development in Jordan or in other developing countries, since one country decisions related to this policy is very important and significant in the economic life of its people, especially after the biggest proof that many of the foreign researchers insisted on the need of the government intervention in economic life after the huge exposure suffered by the world during the recent crisis.

\section{References}

Abu, S. R. (2014). The Causal Relationship between Fiscal Policy and Economic Growth in Jordan. International Journal of Business and Social Science, 5(3).

Agnello, L. R. M. (2012). How Does Fiscal Consolidation Effect on Income Inequality? Review of Income and Wealth, banque de France working paper, No. 382. Retrieved from http://ssrn.com/abstract=2060097

AL-Khasawneh, M., \& Abu, A. K. (2012). The relationship between fiscal policy and economic growth rates: Case Research of Jordan (2004-2011). Interdisciplinary Journal of Contemporary Research in Business, 4(6), 135-149.

Andolfatto, D. (2008). Macroeconomic Theory and Policy (2nd ed.). Munich Personal RePEc Archive.

Annual reports. (1993-2013). Jordan Department of Statistics.

Audu, N. P. (2012). The Effect of Fiscal Policy on the Nigerian Economy. International Review of Social Sciences and Humanities, 4(1), 142-150.

Bandyopadhyay, S., \& Esteban, J. (2007). Redistributive Taxation and Public Expenditures. Department of economics, Discussion paper series. Retrieved from http://www.economics.ox.ac.uk

Bebeşelea, M., Mitran, P. C., \& Neguriţă, O. (2012). Econometric model concerning the impact of the fiscal policy upon the economic development: The case of the countries from central and eastern europe, members of the European Union. Journal of Knowledge Management, Economics and Information Technology. Retrieved from http://www.scientificpapers.org

Chand, S. (n. d). Importance of Fiscal Policy in the Economic Development of India. Retrieved from http://www.yourarticlelibrary.com

Claus, I., Martinez-Vazquez, J., \& Vulovic, V. (2012). Government Fiscal Policies and Redistribution in Asian Countries. Economic working papers. http://dx.doi.org/10.2139/ssrn.2174128

Dye, R. F., \& Merriman, D. F. (1999). The effects of tax increment financing on economic development. Working Paper, No. 75. Retrieved from http://americandreamcoalition-org.adcblog.org

García-Peñalosa, C., \& Elsa, O. E. (2013). Factor Components of Inequality: A Cross - Country Research. Review of income and wealth, 59(4), 689-727. http://dx.doi.org/10.1111/roiw.12054

García-Peñalosa, C., \& Turnovsky, S. J. (2011). Taxation and Income Distribution Dynamics in a Neoclassical Growth Model. Journal of Money, Credit and Banking, 43(8), 1543-1577. http://dx.doi.org/10.1111/j.1538-4616.2011.00458.x

Gow, J., \& Mallick, O. B. (2005). Development theory, Rostow's five stage model of development and its relevance in Globalization. Essays, Issued by the school of science, the university of Newcastle. Retrieved from http://202.202.111.134

Gujarati, D. N. (1999). Essentials of Econometrics (2nd ed., p. 511). Irwin/McGraw-Hill.

Henrekson, M. (1990). Peacock and Wiseman's Displacement Effect: A Reappraisal and a New Test. European Journal of Political Economy, 6(30). http://dx.doi.org/10.1016/0176-2680(90)90054-M

Hussein Ali Al-Zeaud, H. A., Bani Khaled, M. H., \& Jardat, M. (2011). Dynamic Modelling of Fiscal Policy Effects in a Developing Countries the Case of Jordan. Middle Eastern Finance and Economics, 15. Retrieved from http://www.eurojournals.com

Ibi, E. E., \& Opue, J. A. (2012). Fiscal Policy and Economic Development in Nigeria (1960-2011). Journal of Agriculture, Forestry and Social Sciences, 10(1). http://dx.doi.org/10.4314/joafss.v10i1.1

Index mundi, (2014). Jordan Economy Profile 2014. Retrieved from http://www.indexmundi.com

Investopedia. (n. d). What is fiscal policy. Retrieved from http://www.investopedia.com

Iyoha A. M. (2002). Macroeconomics: Theory and Policy (1st ed.). Mareh Publishers P.O. Box 10113, Benin City, Nigeria. 
Kakar, Z. K. (2002). Effect of Fiscal Variables on Economic Development of Pakistan. Romanian Journal of Fiscal Policy, 2(2), 1-10. Retrieved from http://www.rjfp.ro/issues

Kitao, S. (2010). Short-Run Fiscal Policy: Welfare, Redistribution, and Aggregate Effects in the Short and Long Run. Federal Reserve Bank of New York, Staff Reports, No. 442. http://dx.doi.org/10.1016/j.jedc.2010.05.011

Likita. (1999). Elements of Public Finance (1st ed.). Marhel Business Centre 103 Lower Mission Road, Ilaro.

M’Amanja, D., \& Morrissey, O. (2005). Fiscal Policy and Economic Growth in Kenya. Centre for Research in Economic Development and International Trade, University of Nottingham, CREDIT Research Paper, No. 05/06. Retrieved from http://www.nottingham.ac.uk

Muinelo-Gallo, L., \& Roca-Sagale's, O. (2011). Economic growth and inequality: The role of fiscal policies. Australian Economic Papers, 50(2-3), 74-97. http://dx.doi.org/10.1111/j.1467-8454.2011.00412.x

Nageri, K. I., Gunu, U., \& Abdul, F. A. (2013). Corruption and economic development: Evidence from Nigeria. Kuwait Chapter of Arabian Journal of Business and Management Review, 3(2), 46-56. Retrieved from http://www.arabianjbmr.com

Ocran, M. K. (2009). Fiscal policy and economic growth in South Africa. Journal of Economics Studies, 38(5), 604-618. http://dx.doi.org/10.1108/01443581111161841

Olabisi, J. (2009). Tax incentive as a catalyst for economic development in Nigeria. Journal of Research in National Development, 7(2). Retrieved from http://www.ajol.info/index.php

Samuelson A. O., \& Nordhaus, N. (1995). Economic International Edition. McGraw-Hill Inc., N. Y. Journal and Publications.

Somashekar, N. T. (n. d). Development and environmental economics. Retrieved from https://books.google.jo

Thompson, J. P., \& Smeeding, T. M. (2013). Inequality and Poverty in the United States: The Aftermath of the Great Recession. Finance and Economics Discussion Series Divisions of Research \& Statistics and Monetary Affairs Federal Reserve Board, Washington, D.C. http://dx.doi.org/10.2139/ssrn.2340665

Wagner, R. E., \& Warren, E. W. (1977). Wagner's law, Fiscal institutions, and the growth of the government. National Tax Journal, 30(1), 59-68. Retrieved from http://www.jstor.org

\section{Appendix}

Table 1. Per capita income and fiscal policy elements of Jordan during the period (1989-2013)

\begin{tabular}{cccccc}
\hline Fiscal Year & Per capita income & Tax Revenues & Current Expenditures & Capital Expenditures & Total Public Expenditures \\
\hline 1989 & 980.00 & 270.20 & 790.82 & 160.29 & 951.11 \\
1990 & 931.52 & 383.94 & 841.38 & 194.01 & 1035.39 \\
1991 & 870.46 & 460.75 & 903.97 & 195.63 & 1099.60 \\
1992 & 1010.33 & 570.88 & 929.55 & 248.24 & 1177.79 \\
1993 & 1018.85 & 643.37 & 1044.29 & 292.29 & 1336.58 \\
1994 & 1052.68 & 694.50 & 1115.16 & 317.05 & 1432.22 \\
1995 & 1085.28 & 780.30 & 1220.44 & 384.50 & 1604.94 \\
1996 & 1077.85 & 841.05 & 1296.63 & 410.00 & 1706.63 \\
1997 & 1083.12 & 864.50 & 1438.00 & 332.48 & 1770.48 \\
1998 & 1087.51 & 858.66 & 1620.53 & 437.68 & 2058.21 \\
1999 & 1097.12 & 884.20 & 1643.10 & 396.40 & 2039.50 \\
2000 & 1115.64 & 961.90 & 1851.30 & 335.80 & 2187.10 \\
2001 & 1145.88 & 996.40 & 1912.50 & 403.80 & 2316.30 \\
2002 & 1183.62 & $1,000.30$ & 1899.90 & 496.30 & 2396.20 \\
2003 & 1201.77 & $1,083.20$ & 2163.70 & 646.10 & 2809.80 \\
\hline
\end{tabular}




\begin{tabular}{llllll}
\hline 2004 & 1275.46 & $1,428.80$ & 2377.80 & 802.70 & 3180.50 \\
2005 & 1348.37 & $1,765.80$ & 2908.00 & 630.90 & 3538.90 \\
2006 & 1424.44 & $2,133.50$ & 3118.10 & 794.10 & 3912.20 \\
2007 & 1507.78 & $2,472.10$ & 3743.90 & 842.60 & 4586.50 \\
2008 & 1581.55 & $2,758.10$ & 4473.40 & 958.50 & 5431.90 \\
2009 & 1632.14 & $2,884.00$ & 4586.60 & 1444.50 & 6031.10 \\
2010 & 3069.35 & $2,986.30$ & 4746.60 & 961.40 & 5708.00 \\
2011 & 3276.78 & $3,062.20$ & 5739.50 & 1057.10 & 6796.60 \\
2012 & 3438.55 & $3,440.00$ & 6202.80 & 675.40 & 6878.20 \\
2013 & 3640.00 & $3,770.00$ & 6210.10 & 1245.60 & 7455.70 \\
\hline
\end{tabular}

Source: Jordan Department of Statistics. 1993-2013. Annual reports.

\section{Copyrights}

Copyright for this article is retained by the author(s), with first publication rights granted to the journal.

This is an open-access article distributed under the terms and conditions of the Creative Commons Attribution license (http://creativecommons.org/licenses/by/3.0/). 